\title{
A review of ice and tide observations in the Bay of Fundy
}

\author{
Con Desplanque ${ }^{1}$ and David J. Mossman ${ }^{2}$ \\ 127 Harding Avenue, Amherst, Nova Scotia B4H 2A8, Canada \\ ${ }^{2}$ Department of Physics, Engineering and Geoscience, Mount Allison University, \\ 67 York Street, Sackville, New Brunswick E4L 1E6, Canada
}

Date Received April 27, 1998

Date Accepted December 15, 1998

\begin{abstract}
Vigorous quasi-equilibrium conditions characterize interactions between land and sea in macrotidal regions. Ephemeral on the scale of geologic time, estuaries around the Bay of Fundy progressively infill with sediments as eustatic sea level rises, forcing fringing salt marshes to form and reform at successively higher levels. Although closely linked to a regime of tides with large amplitude and strong tidal currents, salt marshes near the Bay of Fundy rarely experience overflow. Built up to a level about $1.2 \mathrm{~m}$ lower than the highest astronomical tide, only very large tides are able to cover the marshes with a significant depth of water. Peak tides arrive in sets at periods of 7 months, 4.53 years and 18.03 years. Consequently, for months on end, no tidal flooding of the marshes occurs. Most salt marshes are raised to the level of the average tide of the 18 -year cycle. The number of tides that can exceed a certain elevation in any given year depends on whether the three main tide-generating factors peak at the same time. Marigrams constructed for the Shubenacadie and Cornwallis river estuaries, Nova Scotia, illustrate how the estuarine tidal wave is reshaped over its course, to form bores, and varies in its sediment-carrying and erosional capacity as a result of changing water-surface gradients. Changing seasons bring about dramatic changes in the character of the estuaries, especially so as ice conditions develop during the second half of the 206-day (7-month) cycle when the difference in height between neap tide and spring tide is increasing, the optimal time for overflow in any season. Maximum ice hazard, including build-up of "ice walls" in Fundy estuaries, occurs one or two months before perigean and spring tides combine to form the largest tide of the cycle. Although "ice walls" and associated phenomena pose hazards for man-made constructions, important natural purposes are served which need to be considered in coastal development and management schemes.
\end{abstract}

Les interactions entre la terre et la mer dans les régions macrotidales sont caractérisées par de vigoureuses conditions de quasi-équilibre. Les estuaires, éphémères à l'échelle stratigraphique, de la région de la baie de Fundy se sont progressivement remplis de sédiments au fur et à mesure que s'est élevé le niveau eustatique de la mer, forçant la formation et la reformation de marais salés en bordure à des niveaux successivement plus élevés. Même si les marais salés voisins de la baie de Fundy sont intimement reliés à un régime de marées de grande amplitude et à des courants de marée puissants, ils débordent rarement. Créés à un niveau d'environ $1,2 \mathrm{~m}$ au-dessous de la marée astronomique la plus élevée, seules les marées très importantes peuvent recouvrir les marais d'une nappe d'eau de profondeur substantielle. Les marées de pointe surviennent regroupées à des intervalles de sept mois, 4,53 ans et 18,03 ans. Par conséquent, aucune inondation des marais ne se produit pendant plusieurs mois de suite. La majorité des marais salés se sont élevés au niveau des marées moyennes du cycle de 18 ans. Le nombre de marées pouvant dépasser une certaine altitude au cours d'une année donnée dépend de la simultanéité de manifestation des trois principaux facteurs de production des marées. Les marégrammes construits dans les estuaires des rivières Shubenacadie et Cornwallis, en Nouvelle-Écosse, illustrent de quelle façon les flots de marée estuariens sont remodelés tout au long de leur parcours pour former des mascarets et dans quelle mesure varie leur capacité d'érosion et de transport de sédiments par suite de la modification de la déclivité en surface des eaux. Les changements de saisons modifient de façon spectaculaire le caractère des estuaires, plus particulièrement lors de l'apparition d'une concentration de glaces au cours de la deuxième moitié du cycle de 206 jours (sept mois) lorsque la différence de hauteur entre la marée de morte-eau et la marée de vive-eau augmente, $\mathrm{c}$.-à-d. la période qui représente le moment le plus propice à un débordement en n'importe quelle saison. Les pires dangers posés par les glaces, notamment la formation des " murs de glace " dans les estuaires de Fundy, surviennent un ou deux mois avant que les marées de périgée et de vive-eau se combinent pour former la marée la plus importante du cycle. Même si les " murs de glace " et les phénomènes connexes posent des dangers aux ouvrages construits, ces marées jouent un rôle naturel primordial dont il faut tenir compte dans les plans d'aménagement et de développement côtiers.

Traduit par la rédaction

"The appearance of an estuary in the Bay of Fundy at any time in midwinter presents some singular and striking phenomena, which may contribute to our knowledge of the manner in which different agents have assisted in excavating this extraordinary bay, and are now engaged in extend- ing its domains in some directions and reducing it in others."

Henry Youle Hind: The ice phenomena and tides of the Bay of Fundy (1875, p. 195) 
Henry Youle Hind, explorer and naturalist extraordinaire, made perceptive observations of various geological phenomena in the Bay of Fundy region. Those dealt with here are processes contributing to the quasi-equilibrium conditions (conditions that vary cyclically but return over the long run to previous conditions) which characterize the vigorous interactions between land and sea, across the seasons, in estuaries in a macrotidal regime at $45^{\circ} \mathrm{N}$. In the Bay of Fundy, as a natural consequence of rising sea level, progressive infilling with sediment occurs as the salt marshes migrate inland, reforming at successively higher levels. Where this process is impeded by artificial sea walls or human settlement, a "coastal squeeze" occurs with resultant erosion (Boorman and Hazelden, 1995; Davis, 1994). In this overview we examine, from seasonal perspectives, some basic tidal processes in Bay of Fundy estuaries, and their implications. Much of the basic data is drawn from observations of the Maritime Marshland Rehabilitation Administration (1950-1965) and from archives of the Maritime Resource Management Services (1972-1987).

\section{Fundy TIDES}

Fundy estuarine processes are closely linked to the tidal regime (cf. El-Sabh and Silverberg, 1990). Bordered at the outer limit by the edge of the continental shelf, the Bay of Fundy tidal system has a resonant period of about 13 hours. This is close to the 12 hour, 25 minute dominant lunar tide of the Atlantic Ocean. Thus, the Atlantic tidal pulse pushes waters of the Gulf of Maine and the Bay of Fundy at nearly the optimum interval to achieve maximum ebb and flow under normal conditions (Greenberg, 1987). Beyond this, as for ocean tides the world over, normal (astronomical) variations in Bay of Fundy tides are mainly due to three factors:

(1) Variable distance between the moon and earth.

This factor causes the greatest deviations from the average (mean) tide in the Bay of Fundy. Because the moon's orbit is an ellipse, once a month when the moon is closest to the earth (and thus the gravitational pull the greatest) the tides are stronger than average. These tides are called "perigean" and the cycle in which they recur is the "anomalistic month" of 27.555 days.

(2) Variable positions of the moon, sun and earth relative to each other.

The cycle of the moon's phases in which there are two sets each, of "spring" and "neap" tides, is the "synodical month" of 29.531 days. The Full and New Moons occur, on average, 14.765 days apart. The terms "spring" and "neap" tides originated along the eastern side of the Atlantic Ocean, where they are the dominant feature in the variation of the tidal heights. However, they are less significant on the North American side. The term "spring" is derived from the Germanic word "springen" -to jump - and has nothing to do with the spring season. The term "neap" has most likely connections with the Germanic word "knipen" - to pinch - which can still be found in the English term "to nip in the bud".

(3) Declination of the moon and sun relative to the earth's equator.

Declination is the angular distance between a heavenly body and the celestial equator (the plane in which the earth's equator is situated). A complete cycle in which the moon crosses the equator twice lasts 27.322 days and is called a "tropical month". Thus, moon declination acts on a cycle of 13.660 days; additional variation depends on revolutions of the moon's node in 18.61 solar years.

Additional factors that influence tides include the earth's rotation and variations in the eccentricity of the moon's orbit. Non-astronomical phenomena include the possible increasing tidal range in the Bay of Fundy due to deepening waters, atmospheric disturbances, the geometric shape of inlets, bays and ocean basins, and the post-glacial rise in sea level, and submergence of the local landmass (cf. Shaw et al., 1994).

\section{FUNDY TIDAL MARSHES AND TIDAL FLOODING}

No two estuaries are the same, and on the geologic time scale, all are ephemeral features. So too are tidal marshes, if only for the fact that any extensive marsh highlights a natural estuary that has been largely infilled with sediment. The Fundytype marsh (cf. Johnson, 1925) is built in a regime of tides with large amplitude and strong tidal currents. Unlike New England marshes and coastal plain marshes, which experience frequent overflow, the Fundy marshes rarely experience overflow.

In the Bay of Fundy, the high silt-carrying capacity of currents causes marshes to build up with mineral matter, which is removed from the bottom, the banks, and the exposed shorelines of the bay. Incoming tide water has a reddish colour and a silt content of about 2 weight $\%$. Tides that rise high enough to flood marshes in the upper reaches of the Bay of Fundy move larger volumes of water at higher velocities and greater eroding and sediment-carrying capacities. During large tides, High Water at the mouth of the bay may extend $2 \mathrm{~m}$ higher than High Water during small tides. In the upper reaches, this difference can exceed $4.5 \mathrm{~m}$. Note, however, that in the upper reaches of the Bay of Fundy (Fig. 1), the sea floor is too high to allow a really Low Water. Therefore, it is better to employ the terms "large" and "small" tides rather than refer to tidal range, the difference between Low and High Water.

In general, tidal marshes in the Bay of Fundy area are built up to a level $1.2 \mathrm{~m}$ lower than the highest astronomical tides. Thus, only large tides can reach marsh levels and only very large tides are able to cover the marshes. For instance, on average, only 52 tides per year [standard deviation (SD) of the variation in tidal occurrences $=12$ ] will be able to reach above the level of the remaining undyked tidal marshes along the Cumberland Basin (Fig. 1). The number of tides that are able to cover the marsh to a depth of $0.5 \mathrm{~m}$ or more is $11(\mathrm{SD}=$ 

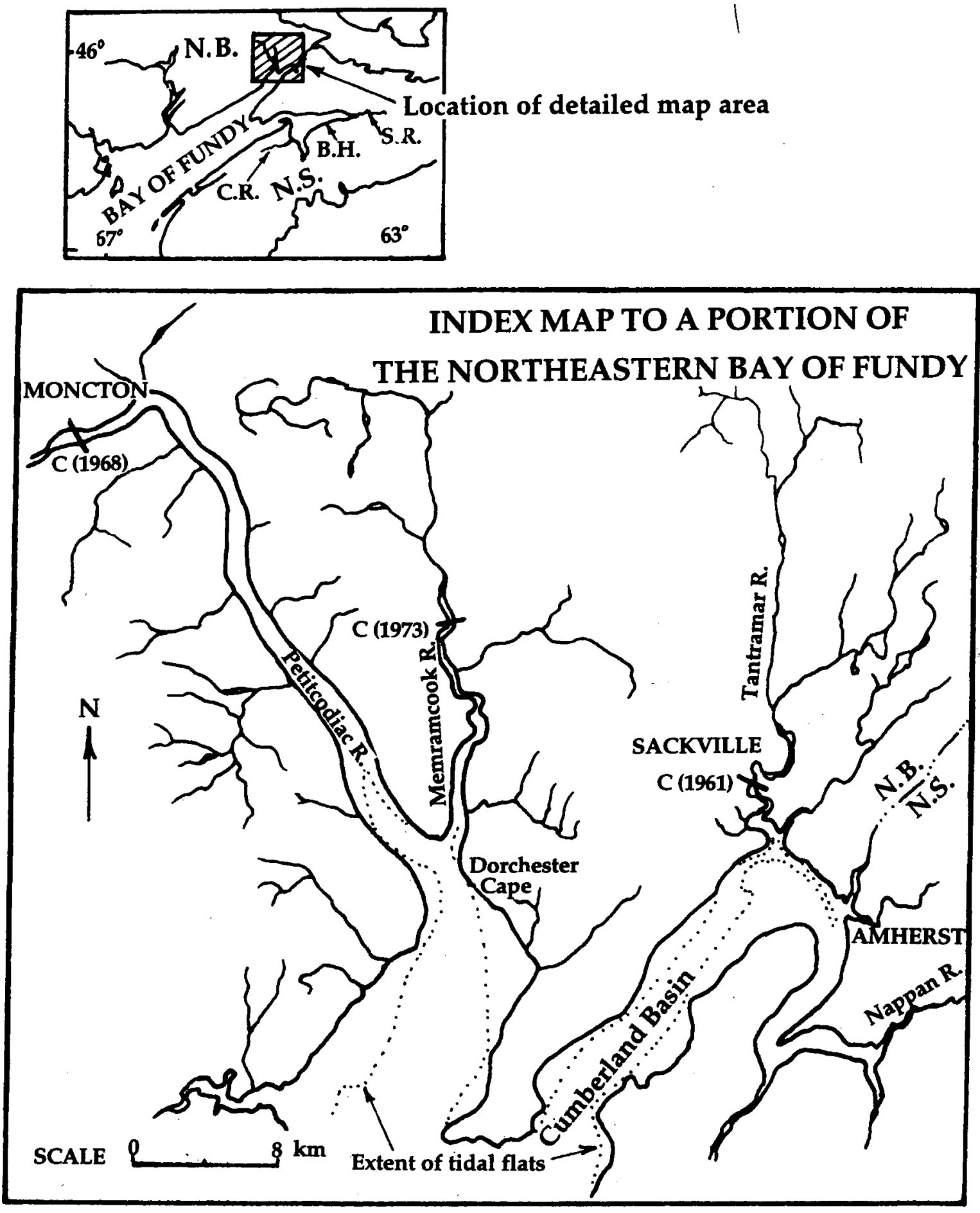

Fig. 1. Index map to a portion of the estuarine system at the head of the Bay of Fundy. S.R. = Shubenacadie River, C.R. = Cornwallis River, B.H. = Burntcoat Head.

5). These peak tides come in sets at monthly intervals, and a group of these sets appear at intervals of 7 months, 4.53 years and 18.03 years. Consequently, for months on end no tidal flooding of the marshes will take place. As a corollary to this, it would be wrong to view Fundy tidal marshes as natural hatcheries or nursery areas for salt water fish (Gordon $e t$ al., 1985). However, when an overflow does occur, the silt content tends to be far higher than usual. Silt deposition on the marsh depends on the frequency of tidal flooding and the silt content of the tidal water. In the upper reaches of the bay, the silt content is much greater than near the mouth of the bay, although the frequency of tidal flooding is much less. Which factor is of greater consequence is open for debate. Sediment deposition upon the marsh causes a rise in elevation of the marsh in the same order as the rate of submergence of the region.

In summer, the soil can dry out, producing mud cracks up to $5 \mathrm{~cm}$ wide and $40 \mathrm{~cm}$ deep, a geological feature generally 
taken to signify prolonged aridity. The vegetation on such areas must be able to tolerate occasional flooding with siltladen salt water, alternating with long dry spells (Gordon $e t$ al. 1985). Few species of plants are able to do this. Spartina alterniflora, a pioneer in this environment, is able to withstand the effects of frequent flooding. However, even this plant has its limitations, and is able to grow in tidal creeks only to a level $1 \mathrm{~m}$ below the marsh surface. The lower parts of the creek are bare of plant life. On the flat high marsh, another species, Spartina patens, is short and dense, promoting its requisite moist soil conditions over reasonably long intervals of time. Unfortunately, neither plant contributes much fertility to the marsh because they are low in plant nutrients such as calcium and phosphate. Nor is fertility enhanced by the silt-rich tidal marsh soils which consist mainly of rather coarse-grained silicates. These silicates offer far less in terms of ion exchange capacity than, for example, the calcium-rich clays of western European marshlands, or for that matter, New England marshlands (Desplanque, 1952). As we shall see, intertidal flats of estuaries may vary seasonally, storing clay and silt during the summers, and freeing them to winter waters (Amos, 1995).

The apparent contradiction that marshes in areas with strong tides are less often covered with sea water than those where tidal amplitudes are low, is explained by reference to
Table 1. Here, the height of High Water has been measured from Chart Datum (CD), the average of the lowest predicted annual low water level over an 18.61 year period. Mean Sea Level (MSL) in the Maritimes has been rising relative to the landmass during the past several thousand years. Using all the hourly readings taken from 1927 to 1975 , the variable distance between MSL and CD at Saint John, New Brunswick, can be expressed as:

$$
\begin{aligned}
\mathrm{Z}_{0} & =13.666+0.011834 \cdot(\mathrm{Y}-1927) \mathrm{ft} \\
& =4.165+0.003607 \cdot(\mathrm{Y}-1927) \mathrm{m}
\end{aligned}
$$

where $Z_{0}$ is the vertical distance that MSL is higher than CD on January 1 of the year Y.

Thus, on January 1,1956 , the value of Zo was $4.270 \mathrm{~m}$ or $14.010 \mathrm{ft}$ (MMRA, 1950-1965). In Table 1 , this value is used to estimate tidal amplitudes over a ten-year interval. These data were used to calculate the S-shaped curve of Figure 2, which shows the number of tides per year that will reach or exceed certain levels above Mean Water Level. According to the Canadian Tide and Current Tables (p. VI), Mean Water Level (MWL) is defined as the height above CD of the mean of all hourly observations used for the tidal analysis at that particular place. At Saint John, New Brunswick, there is most

Table 1. Number of times per year that tides at Saint John, New Brunswick reached to, or above, certain heights above Chart Datum (CD) and Mean Sea

\begin{tabular}{|c|c|c|c|c|c|}
\hline \multirow{2}{*}{$\begin{array}{c}\text { Height } \\
\text { above } \\
\text { CD } \\
\text { in } \mathrm{ft} .\end{array}$} & \multirow{2}{*}{$\begin{array}{l}\text { Height } \\
\text { above } \\
\text { MSL } \\
\text { in } \mathrm{ft} .\end{array}$} & \multirow{2}{*}{$\begin{array}{l}\text { Height } \\
\text { above } \\
\text { MSL } \\
\text { in } m\end{array}$} & \multicolumn{3}{|c|}{$\begin{array}{l}\text { Number of events } \\
\text { during one year }\end{array}$} \\
\hline & & & Minimum & Mean & Maximum \\
\hline 29.5 & 15.171 & 4.624 & 0 & 0.05 & $1(1953)$ \\
\hline 29.0 & 14.671 & 4.472 & 0 & 0.15 & 1 (1953) \\
\hline 28.5 & 14.171 & 4.319 & 0 & 2.20 & 7 (1963) \\
\hline 28.0 & 13.671 & 4.167 & $3(1948)$ & 9.95 & $20(1963)$ \\
\hline 27.5 & 13.171 & 4.014 & $12(1948)$ & 26.15 & 38 (1962) \\
\hline 27.0 & 12.671 & 3.862 & 30 (1951) & 50.35 & 77 (1958) \\
\hline 26.5 & 12.171 & 3.710 & 55 (1951) & 83.95 & 114 (1958) \\
\hline 26.0 & 11.671 & 3.557 & 94 (1950) & 129.00 & $167(1961)$ \\
\hline 25.5 & 11.171 & 3.405 & $138(1950)$ & 189.95 & $236(1960)$ \\
\hline 25.0 & 10.671 & 3.253 & 190 (1949) & 266.80 & $323(1960)$ \\
\hline 24.5 & 10.171 & 3.100 & 252 (1949) & 351.65 & 430 (1960) \\
\hline 24.0 & 9.671 & 2.948 & 338 (1949) & 437.30 & 503 (1963) \\
\hline 23.5 & 9.171 & 2.795 & $428(1949)$ & 513.30 & 582 (1958) \\
\hline 23.0 & 8.671 & 2.643 & 497 (1949) & 579.15 & 644 (1958) \\
\hline 22.5 & 8.171 & 2.491 & 584 (1949) & 633.05 & 679 (1958) \\
\hline 22.0 & 7.671 & 2.338 & 636 (1949) & 668.60 & $697(1962)$ \\
\hline 21.5 & 7.171 & 2.186 & 677 (1950) & 690.35 & 704 (1958) \\
\hline 21.0 & 6.671 & 2.033 & $689(1950)$ & 701.25 & 705 (1958) \\
\hline 20.5 & 6.171 & 1.881 & 699 (1950) & 704.15 & 706 (1956) \\
\hline 20.0 & 5.671 & 1.729 & 703 (1951) & 705.25 & 708 (1958) \\
\hline 19.5 & 5.171 & 1.576 & 704 (1955) & 705.45 & 708 (1956) \\
\hline
\end{tabular}
Level (MSL) during a 20-year interval (1947-1966). 


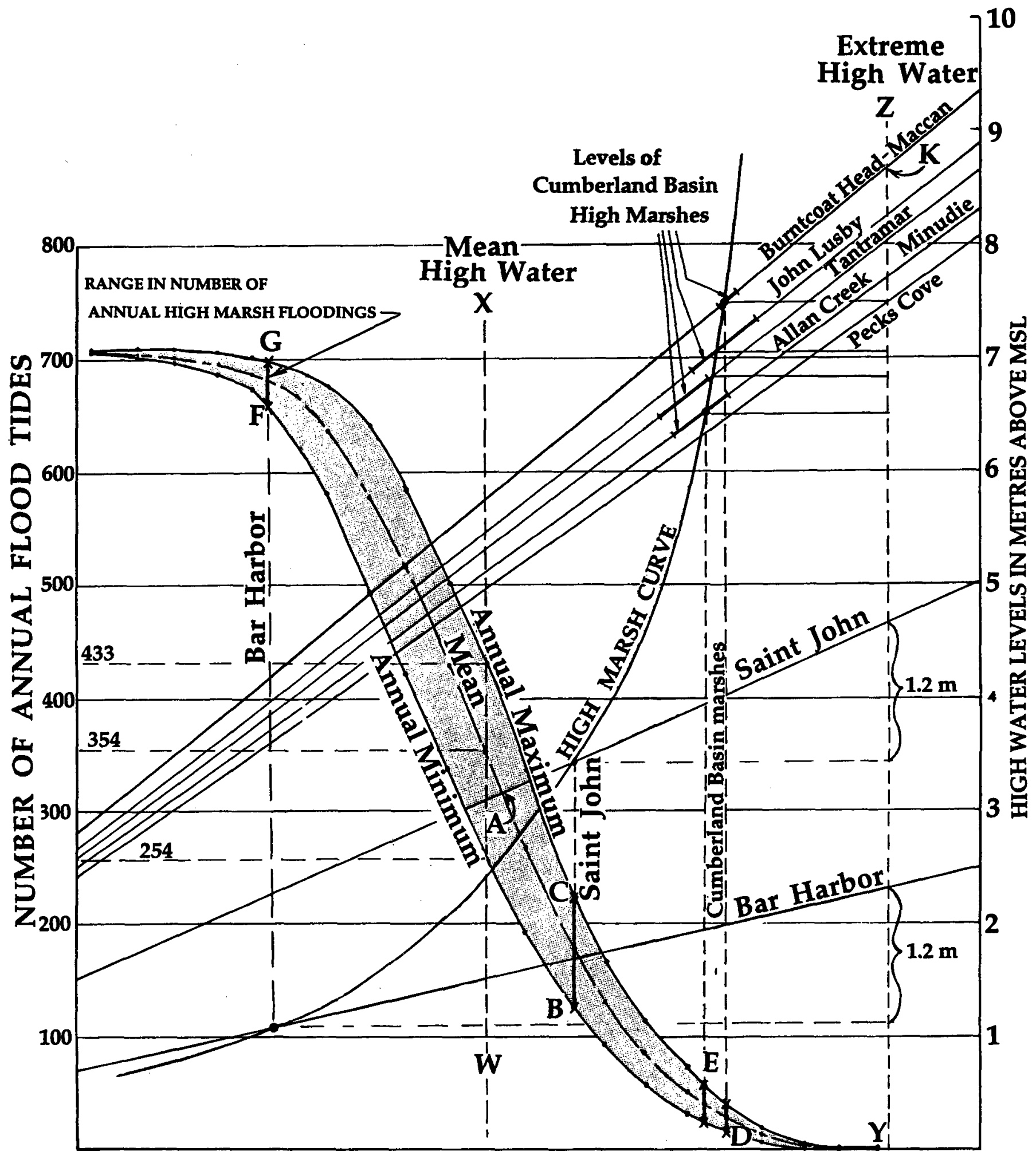

Fig. 2. Combination chart showing the number of tidal floodings (read off the vertical axis) that can exceed a certain level on Bay of Fundy Marshes, based on observed tidal heights at Saint John, New Brunswick (1947 through 1966). The straight sloping lines for Bar Harbor, Saint John, Pecks Cove and Cumberland Basin high marshes give the corresponding tidal ranges. Mean High Water (MHW) and Extreme High Water (given in official Tide Tables for each station) are marked by the intersection of the sloping lines with WX and YZ, respectively. The Extreme High Water Level above Mean Sea Level (MSL) reached, for example at Burntcoat Head-Maccan, and read along $\mathrm{YZ}$ at $\mathrm{K}$, is $8.7 \mathrm{~m}$. The MHW level (A) at Saint John is about $3.1 \mathrm{~m}$ above MSL. The High Marsh Curve is an empirical auxiliary curve to determine the number of annual floodings of tidal marshes. Local marsh level is assumed to be $1.2 \mathrm{~m}$ below the high water level during extreme high tides. Where the High Marsh Curve crosses the sloping lines for the given tidal stations; vertical lines extended to intersect the S-shaped set of curves show the annual number of expected tidal floodings of out-to-sea marshes. Thus, for Bar Harbor, the number of floodings ranges between $660(\mathrm{~F})$ and 700 (G); for Saint John, between 130 (B) and 230 (C); for marshes along the Cumberland Basin, the number of floodings ranges from only about 15 (D) to $60(E)$. (See text for further details.) 
likely a changing difference in elevation between the MWL and the Geodetic Datum, hence MWL is used because it is linked to the local tidal movements.

Figure 2 is known as a combination chart or nomograph of a type widely used in engineering (Davis, 1943); it does not have a horizontal axis (abscissa). This "chart" employs a natural scale (rather than logarithmic) and displays the results of calculations which combine various functions (i.e., multiplication or division with addition or subtraction) based on observed tides at Saint John, New Brunswick. The strength of the tides at several other stations in the region are represented in Figure 2 by lines, the slope of which is determined by the distance from the reference point $(0 \mathrm{~km})$ of Bar Harbor, Maine.

From Bar Harbor, Maine, to the head of the Bay of Fundy, the range of the dominant semi-diurnal tides increases in magnitude exponentially at the rate of about $0.36 \%$ per $\mathrm{km}$. This rate is equivalent to $3.56 \%$ per $10 \mathrm{~km}, 41.8 \%$ per $100 \mathrm{~km}$, etc. Given this $0.36 \%$ exponential increase in tidal range, when the high water level at Bar Harbor is $1 \mathrm{~m}$ above MSL, the level 196 $\mathrm{km}$ distant at Saint John can be calculated in the same manner as compound interest. The type of calculation is, of course, based on an exponential growth, and in this instance yields about $1 \times 1.0036^{196}=2.02 \mathrm{~m}$. Similarly, the ratio between Bar Harbor water levels and those $366 \mathrm{~km}$ distant at Burntcoat Head is $1 \times 1.0036^{366}=3.73 \mathrm{~m}$.

Most salt marshes in the Bay of Fundy are raised to the level of the average tide, that is the MWL, in the 18-year cycle. Also, the number of high tides per year will vary considerably, depending on the phases of the three main tidegenerating astronomical factors. As shown in Table 2, these coinciding peaks run in cycles of $0.53,4.53$ and 18.03 years, a fact already well established in ancient times.

Applied to variations in the levels of Bay of Fundy tides, the High Marsh Curve on Figure 2 follows places where the local marsh level is assumed to be $1.2 \mathrm{~m}$ below the high water level during extreme high tides. It simply shows that the frequency of tidal flooding is much less in the upper reaches of the Bay of Fundy than in places near its mouth. Drawn from a large data base, the S-curve in Figure 2 shows the range in number of tides that can exceed a certain level. Taking the marsh level as an example, this level at Saint John is approximately $3.5 \mathrm{~m}$ above MSL. The intersection with the S-curve shows that, at Saint John, the marsh will be flooded between 130 to 230 (C-B) times a year, depending upon when it happens during the 18-year cycle. At Bar Harbor, the number of annual floodings is between 660 and 700 (F-G), whereas the Cumberland marshes can expect only about 15 to 60 floodings a year (D-E).

The number of tides/year that will exceed a certain level at a given location is readily determined from Figure 2 . For example, with reference to Mean High Water (line X-W on Fig. 2), a minimum of 254 tides/year, or a mean of 354 tides/ year, or a maximum of 433 tides/year (read off the ordinate), will exceed an elevation of $1.55 \mathrm{~m}$ (above MSL) at Bar Harbor, $3.10 \mathrm{~m}$ at Saint John, and 5.75 at Burntcoat Head (and $7.65 \mathrm{~m}$ at Truro!). Although the data for Truro are not included on Figure 2, the last number illustrates the point that although the tide level at Truro exceeds that at Burntcoat Head, the tidal range is less at Truro because the floor of the estuary is higher at Truro.

\section{EbB AND FLOW IN ESTUARIES}

The volume of an estuary upstream of an arbitrarily chosen cross-section is conveniently divided into two parts. The tidal prism is the top part of the estuary between the Low Water and the High Water levels. Below the Low Water level is the tidal volume. Because tides are variable in strength, the tidal prism and tidal volume are also variable, as is the wet cross-sectional area, which is that part of the total crosssectional area filled with water. It is through this wet area that the water which fills the tidal prism must flow. The upper parts of an estuary may become virtually empty during Low Water. Water levels in the estuary are only able to match the rising tide if enough water flows through the available crosssectional area to fill the tidal prism to the level reached by the tide. In many cases, this situation is physically impossible, as the maximum current speed possible in a cross-sectional area is limited, being proportional to the square root of the water depth (Kjerfve, 1988). Rectangular cross-sectional areas are able to discharge much more water than either parabolic or triangular cross-sectional areas because the larger cross sections allow higher current velocities.

In channels that empty, or nearly so, during Low Water, the first water to return after the turn of the tide is very much restricted moving into the estuary, even discounting friction, because the water depth and cross-sectional area are very small, or zero. However, the following water finds a partly filled channel and can thus move faster and at a greater discharge rate. However, as long as the discharge is inadequate to fill the tidal prism at the same rate of rise of water surface as the outside water, the result is that the seaward gradient of the incoming water will initially have a strong upward curvature. This curvature may become so strong that a vertical wall, known as a bore, forms at the bottom of the incoming wave.

What happens when, at a certain location in the estuary, the water reaches its highest level? Certainly, the more upstream parts of the estuary remain unfilled with water. Seaward of this point, the water level is already falling. Thus, water continues moving landward on its own inertia when the high tide level is reached at that point. As a result, the water surface has already dropped before the direction of flow reverses. Therefore, the time of peak elevation and zero velocity are not coincident. When the water ceases its advance into the estuary, it has already a considerable slope seaward. Soon a sizable seaward current develops, occupying a smaller cross-sectional area than when it moved into the estuary on the rising tide. The falling water level may at first follow the outside tide rather well because of the large cross-sectional areas, but progressively the reduced depth restricts water outflow. Consequently, the seaward gradient of the water surface during ebb flow now has a downward curvature.

In terms of sediment transport, this means that while the incoming tide is at high levels and gradually reducing in speed, 
Table 2. Analysis using simple multiples of astronomical cycles governing the tides shows that the peaks of $\mathrm{P}=$ perigean cycles (27.554 days), $\mathrm{S}=$ spring tides (14.765 days), and declinational cycles (13.661 days) closely coincide at the intervals indicated. The closest coincidence occurs at an interval of 18.03 years.

\begin{tabular}{llll}
\hline \multicolumn{1}{c}{ Perigean } & \multicolumn{1}{c}{ Spring } & \multicolumn{1}{c}{ Declinational } & Period \\
\hline $7 \mathrm{P}=192.88$ & $13 \mathrm{~S}=191.95$ & $14 \mathrm{D}=191.25$ solar days & $=0.53$ years \\
$60 \mathrm{P}=1653.27$ & $112 \mathrm{~S}=1653.71$ & $121 \mathrm{D}=1652.96 " ~$ & $=4.53$ years \\
$239 \mathrm{P}=6585.54$ & $446 \mathrm{~S}=6585.32$ & $482 \mathrm{D}=6584.50 " \quad$ & $=18.03$ years
\end{tabular}

its sediment carrying capacity is reduced. Much of the released sediment is spread over the full height of the channel banks, and during very high tides, over the salt marshes also (Postma, 1967). However, the outgoing tide is concentrated toward the bottom of the channel, having at times, higher speeds than the incoming tide. This situation promotes erosion through undercutting of the channel banks. Excess material high on the banks will slide down, resulting in unstable soil conditions. In testimony, the banks of tidal creeks and rivers in the Bay of Fundy region are characteristically bare of any vegetation, except perhaps for some being transported downslope by undercutting (Scott, 1980). Vegetation is able to take root only where currents are slight. Overall, the intertidal flats of estuaries may vary seasonally, storing clays and silts during summers and removing them during heavy freshwater run-offs.

\section{RESHAPING OF THE TIDAL WAVE}

As the tidal wave enters a shallow estuary its sinusoidal symmetry becomes distorted. The rising limb of the curve becomes compacted within a shorter period, whereas the period of the falling tidal wave increases.

The manner in which a tidal wave may be reshaped as it moves into an estuary is well illustrated by conditions in the Shubenacadie and Cornwallis river estuaries in Nova Scotia (Fig. 3). At the mouth of the Shubenacadie estuary, the rising tide is somewhat retarded by the shallow waters of Cobequid Bay (see Fig. 3). However, the centreline ( $\left.\mathrm{CL}_{1}\right)$, being the locus halfway between rising and falling tide levels at Black Rock, at the mouth of the river, is almost straight and vertical in the uppermost part of the marigram. This means that there is little distortion in the symmetrical shape of the local tide wave. The near vertical rise of the tide at the bottom of the incoming tide wave $(\mathrm{K})$ indicates that a bore may possibly develop.

The curvature (asymmetry) of the centre lines at locations further upstream indicates that the tidal wave is becoming increasingly distorted with much steeper rises of the tide, and slower rates of drop. Meanwhile, the thalweg (the median line of the channel) of the estuary is rising at some distance beneath points $K, L, M, N$ and $O$ (which indicate the water level in the river before the tide wave arrives), thus increasingly limiting the inflow of tidal water. The High Water levels rise for about the first $8.3 \mathrm{~km}$ (A to B, Fig. 3) before gradually dropping ( $B$ to $E$ ). This situation is reflected by the asymmetry of the marigrams, as indicated by the increasing curvatures of their centrelines $\left(\mathrm{CL}_{1}\right.$ to $\left.\mathrm{CL}_{5}\right)$ with distance from the river mouth. Eventually, the water levels in the river will fall back to $\mathrm{K}, \mathrm{L}, \mathrm{M}, \mathrm{N}$ and $\mathrm{O}$, as the water exits the estuary prior to the next incoming tide.

Figure 4 shows the reshaping of the tidal curve in the uppermost $4 \mathrm{~m}$, near the peak of the tide, for a tidal wave in the Cornwallis River, Nova Scotia. The asymmetry of the marigrams, and the shape of the centrelines ( $\mathrm{CL}_{1}$, etc.) show that the further the wave goes into the estuary (Site \#1 to Site \#5), the slower the rate of rise of tide near the peak (A, B, etc., on Fig. 4), and the faster the drop after the peak has passed. Initially, the curvature of the centrelines is reversed near the top of the wave (e.g., A), but further upstream (e.g., D) this reversal disappears.

Figure 5 shows the momentary gradients of the water surfaces at different times during the passage of the top of the Cornwallis River tidal wave. While the wave is moving upstream on its own inertia through this section (between 12.15 and 13.30 hours), the gradients of the water surface seaward of the wave top are negative and rather uniform. However, the moment its inertia is spent, the water starts moving backward toward the sea. The difference is that now, on the outflow, the gradients are not only reversed but steeper because water levels have dropped considerably, forcing flow through small cross-sections at higher velocities. Note too, that the water's surface is curved downward, concentrating the flow of outgoing water in the lower section of the channel.

The difference between tidal rivers and tidal creeks is that tidal rivers discharge freshwater from upland watersheds. In the upper reaches of the estuary, freshwater flow maintains a drainage channel, the size of which is related to the river discharges. In contrast, a tidal creek is formed by tidal water that moves onto a tidal marsh during the higher High Waters, discharging following the turn of the tide. The only freshwater moving in such creeks is rainwater collected on the salt marsh itself. But the point is that creek formation requires a certain area of marsh because the erosion process demands a minimum flow volume from the marsh in order to initiate channel cutting through vegetated soil. For this reason, there always exists a margin of land not cut by tidal creeks on the 


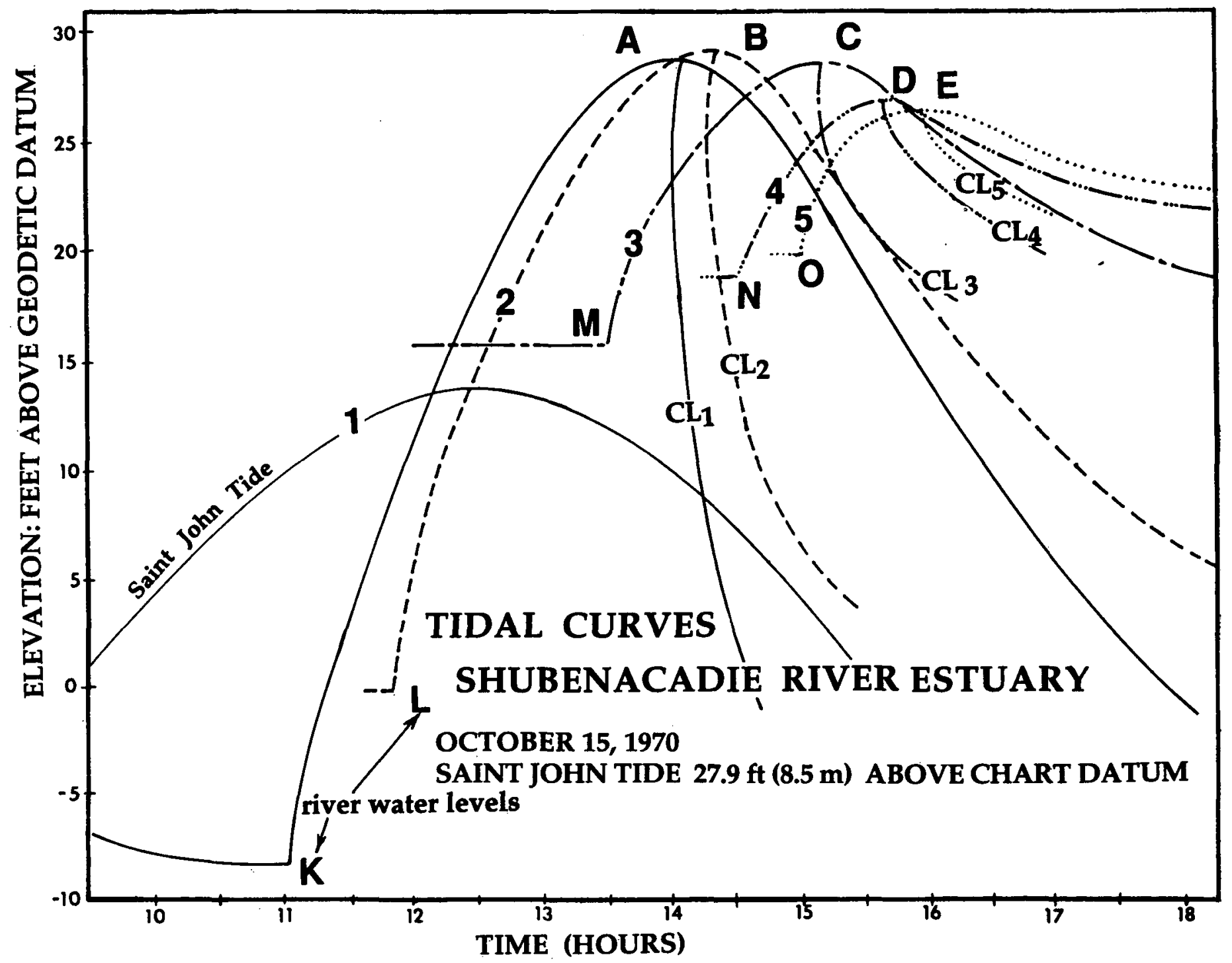

Fig. 3. Curves 1 through 5 indicating modifications to the shape of the tidal wave at various cross-sections of the Shubenacadie River, near Truro, Nova Scotia on October 15, 1970: (A) Black Rock, at mouth of the river, (0 km); (B) Dominion Atlantic Railway (DAR) bridge, $5.3 \mathrm{mi}(8.53 \mathrm{~km})$ upstream; (C) Fort Ellis - Stewiacke River, $14.7 \mathrm{mi}(23.65 \mathrm{~km})$ upstream; (D) Shubenacadie high water bridge, $20 \mathrm{mi}(32.18 \mathrm{~km})$ upstream; and (E) mouth of Gays River, $24 \mathrm{mi}(38.62 \mathrm{~km})$ from the Shubenacadie River's mouth. Saint John tide was $27.9 \mathrm{ft}(8.50 \mathrm{~m})$ above Chart Datum at 11:30 AST. CL is the centreline of the tidal wave and the high water levels are A, B, C, D, and E. The points $K, L, M, N$, and $O$ indicate the initial freshwater level at the location (e.g., $K=$ Black Rock) at the time (in hours) indicated. Data drawn from MMRA observations. (See text for details.)

seaward side of dykes built on reclaimed salt marshes. This feature is readily visible on aerial photographs of out-to-sea marshes.

Tidal channels reach a quasi-equilibrium condition ranging between certain limits. River discharges in spring erode silt deposited during the summer and early fall when the river flows are greatly reduced; consequently, river bottoms may accrete or erode as much as $\mathbf{2} \mathrm{m}$. Before dyke construction, the tidal marshes served as sinks for excess sediment in the system. However, since dyke construction, the increased amount of suspended material will have resulted in drastic changes to the habitats of various forms of marine life.

Uplands form the landward limit of the high marsh, or in the case of extensive salt marshes, freshwater bogs. The latter situation can be explained by the fact that most of the sedimentation that occurs when sediment-charged tidal water floods the marsh happens soon after entering the marsh, forming a natural levee. Thus, between the tidal estuary and the upland, a pond is formed. With submergence of the landmass, the levee becomes higher, and the pond, which receives thinner layers of fine-grained material, becomes deeper and extended horizontally. At a late stage of development, the far reaches of these ponds receive hardly any salt water, thus allowing freshwater vegetation a chance to develop.

\section{WINTER CONDITIONS}

The transition from fall to winter in the Bay of Fundy is a time of stark contrasts. Huge amounts of ice can be formed 


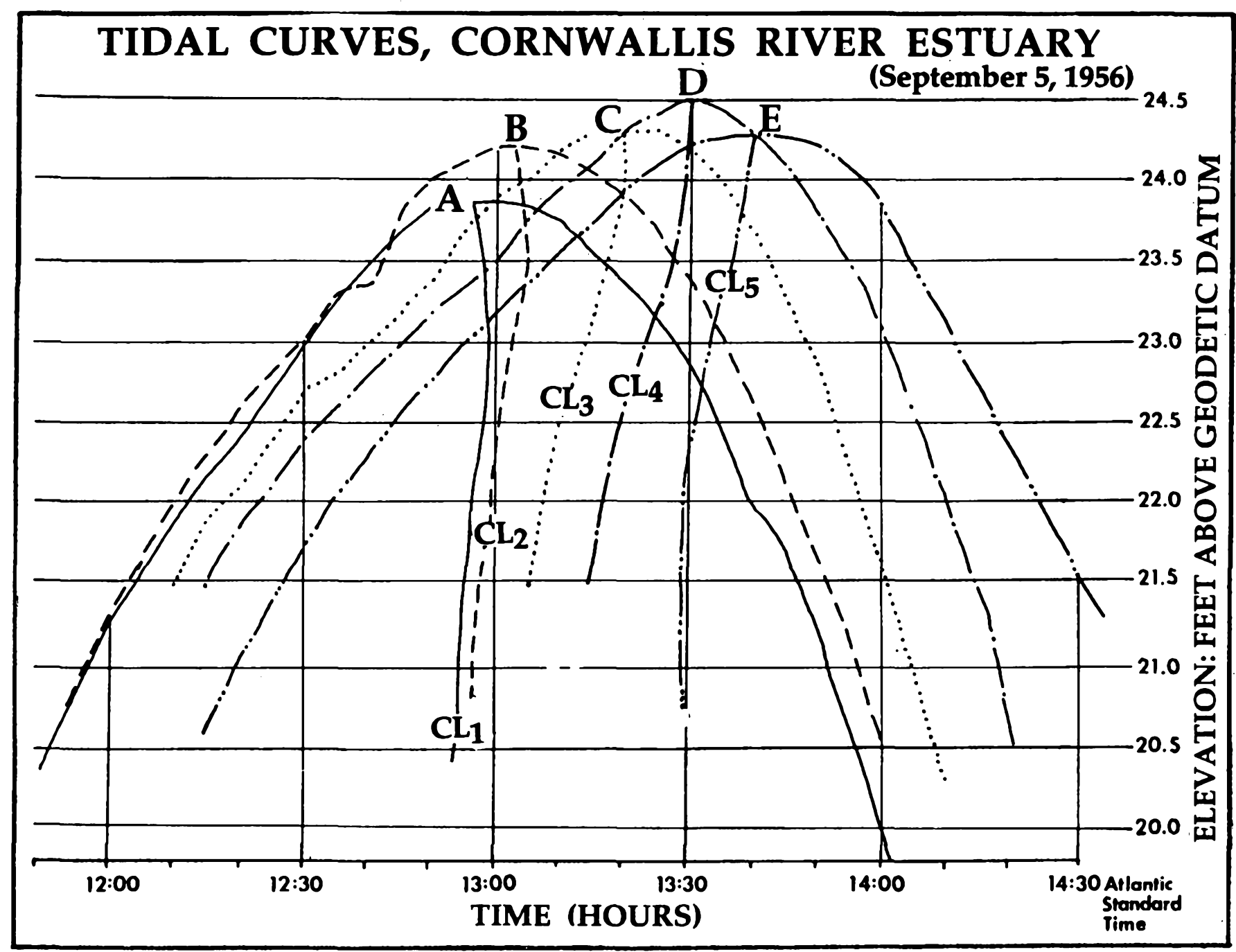

Fig. 4. Observed tidal curves at five stations, illustrating modifications to the shape of the tidal wave in the Cornwallis River, near Digby, Nova Scotia, on September 5, 1956. Station 1, (Port Williams bridge), $0 \mathrm{~km}$ upstream; Station 2, $2 \mathrm{mi}$ (3.2 km) upstream; Station 3, $6 \mathrm{mi}(9.75 \mathrm{~km})$ upstream; Station 4, $8 \mathrm{mi}(13.1 \mathrm{~km})$ upstream; Station 5, $9 \mathrm{mi}(14.3 \mathrm{~km})$ upstream. High water in the St. John River at $27.4 \mathrm{ft}$ above $\mathrm{CD}$ at $11.43 \mathrm{AST}$. Data drawn from MMRA observations. The five centre lines indicate loci halfway between the rising and falling tide levels. Note: the measurements apply only to the uppermost $4 \mathrm{~m}$ of the tidal wave. (See text for discussion.)

during a few days of heavy frost. This situation can bring about a dramatic change in the character of Fundy tidal estuaries (Knight and Dalrymple, 1976; Jennings et al., 1993). Typically, the "ice factories" in open areas of the Cumberland Basin, for example, begin by churning out large volumes of slush, or 'frazil ice'. In a matter of hours, pan ice (an accumulation of slush ice frozen together in flat sheets up to $15 \mathrm{~cm}$ thick), and cake ice (thicker accumulations of pan ice produced in fast moving, ice-packed waters) appear. Blocks of composite ice, protruding half a metre or more above the surrounding ice appear later, likewise large sheets of floe ice (frozen assemblages of other types of floating ice) formed where salinity and tidal energy are reduced. Moving restlessly with the tides, up and down the estuaries, a lot of this material becomes stranded on the foreshore of the estuary, i.e., the zone between the Low and High Water marks.

Following Desplanque and Bray (1986), the foreshore is here divided into three subzones (see also Fig. 6). The upper subzone is the vegetated high marsh which, in the upper reaches of the Bay of Fundy, is approximately $1.2 \mathrm{~m}$ below the highest levels that tides normally reach. Dominated by river-related processes, this subzone is not often covered with tidal water. During some winters, tides do not reach this level, in which case the high marsh escapes ice deposition (Dionne, 1989). However, frozen crust, another major type of ice, usually forms on the surface of the intertidal sediment. This "shorefast ice" results from the combined action of downward-freezing pore water, upward accretion of precipitation, run-off and, depending on the season, sea water.

With increasing strength of the tides, the middle subzone of the foreshore gradually fills with all types of floating ice, most of it brown. Pan ice penetrates marsh creeks, becoming stranded on their banks. On higher parts of the foreshore, stranded ice is left longer exposed to freezing air temperatures, and is more likely to become anchored to the banks (Sweet, 1967). Commonly, ice may become bonded so strongly to a clay or silt substrate that it will not refloat when covered by the tide. In contrast, the connection between ice stranded 


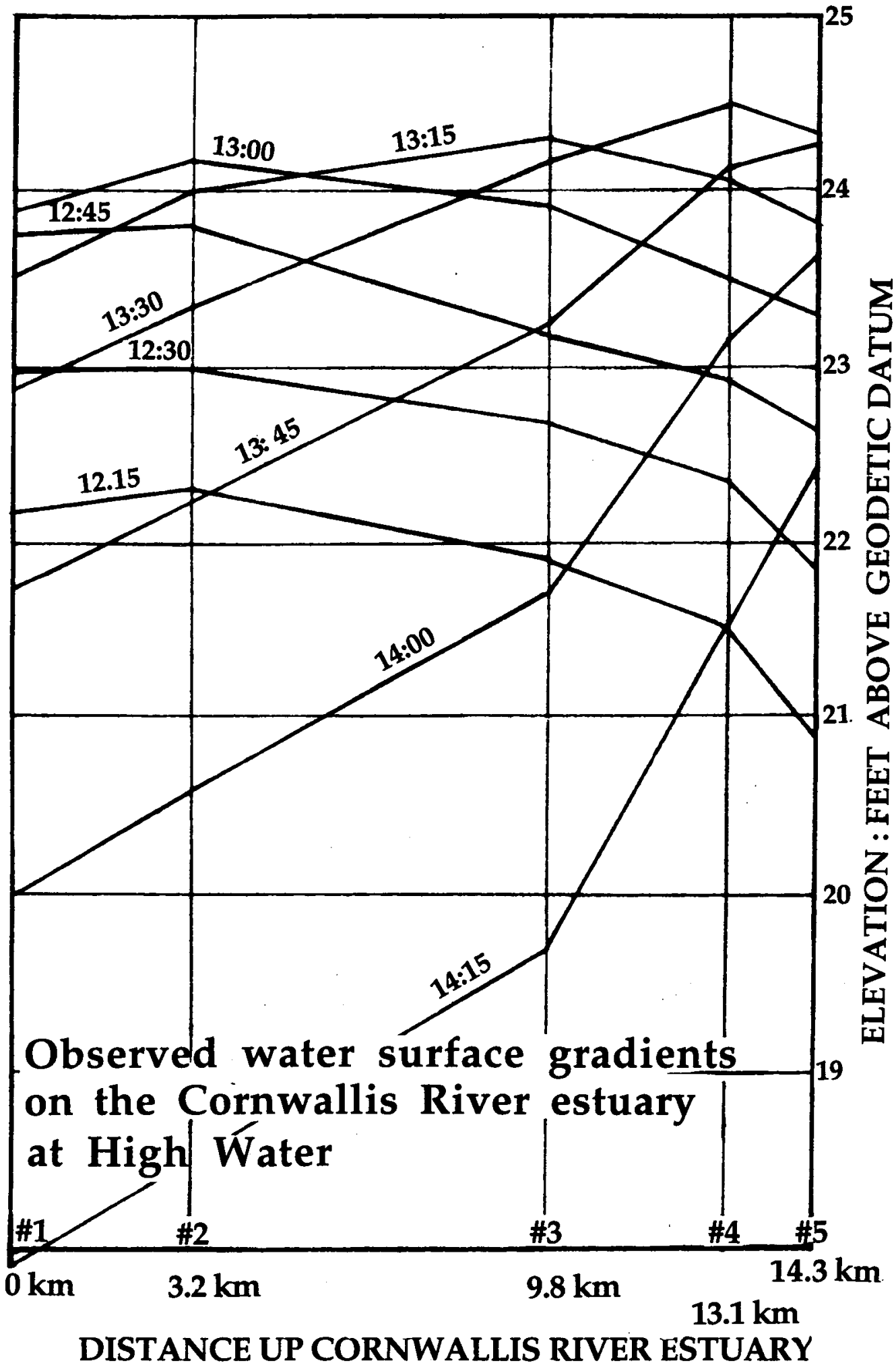

Fig. 5. Observed water surface gradients at different stages on the Cornwallis River, Nova Scotia, using measurements taken only near the peak of the tide, on September 5, 1956. (Times tie in with those shown on Figure 4.) Note the relatively uniform gradient of the water surface of the rising water (time 12:15 to 13:15) compared with the progressively steeper gradient during reversed flow in the channel (see text for discussion). Location\#1@0 mi $(0 \mathrm{~km})$ mouth of the Cornwallis River; \#2@2 mi (3.22 km) upstream; \#3@6 mi (9.65 km) upstream; \#4@8 mi (12.87 km) upstream; \#5@9 mi (14.48 km) upstream. High water on the St. John River was $27.4 \mathrm{ft}$ above Chart Datum at 11:43 AST. Data drawn from MMRA observations.

on gravel or loose rock is rather more fragile. Sheet ice, formed in the lower subzone of the foreshore moves up and down with the tides because the substrate cannot freeze during the shorter exposure to supercooled air. This vertical movement of the ice sheet creates a bellows-like action between the ice and soft mud, promoting vigorous erosion. 


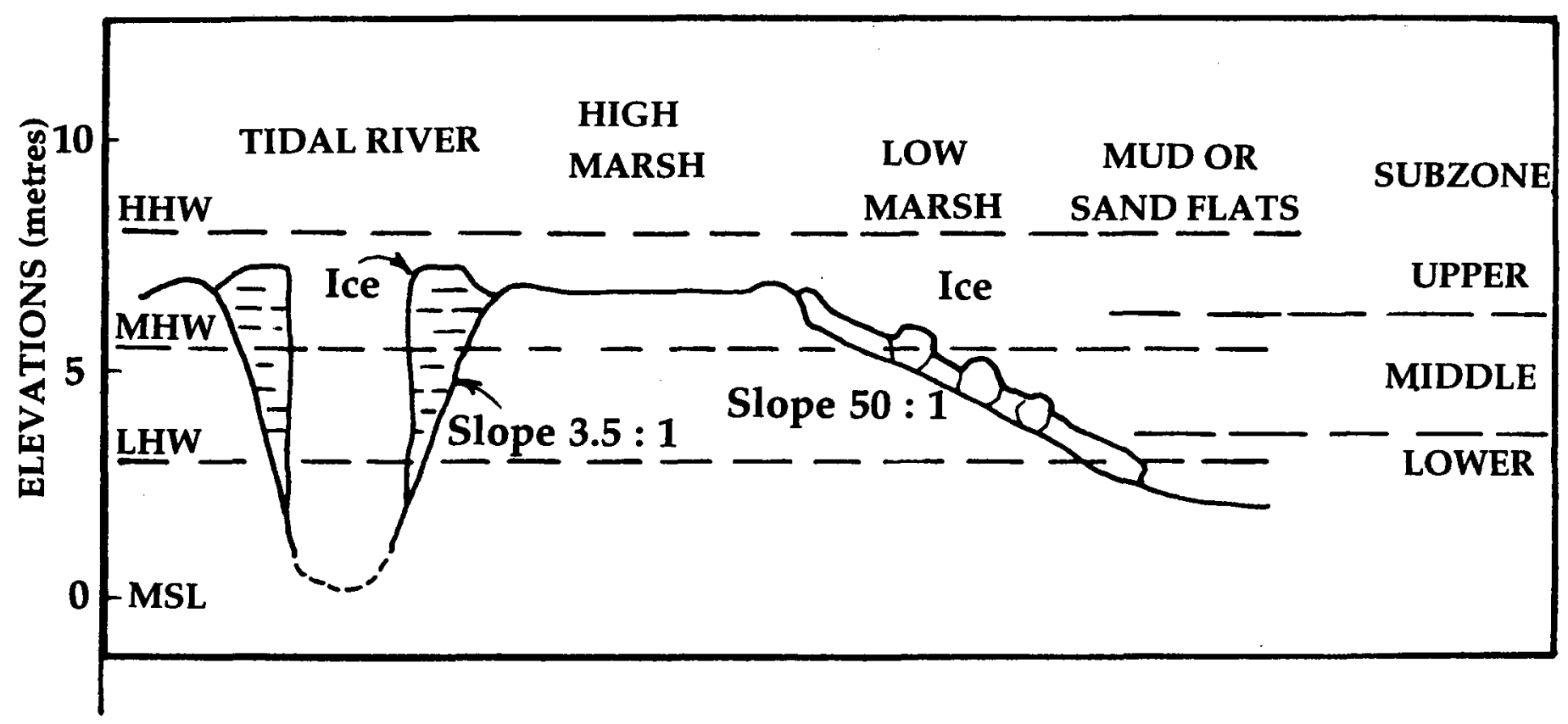

Fig. 6. Different types of shorefast ice along tidal rivers and the upper edge of tidal flats. High marsh areas can be invaded by sea ice only during winters of extreme tides. Lower edge of shorefast ice bordering tidal flats may be floated at high tide. Slopes and generalized subzones (lower, middle and upper) as indicated; see text for discussion (modified after Desplanque and Bray, 1986).

\section{The Phenomenon of ICE WALLS}

In upper reaches of the estuaries, the sea water can bring in ice that will gradually build up high vertical walls. Forced into the ever narrowing sections of the estuary by a sort of ratchet movement, the ice is unable to exit. Initially, ice walls are rather porous and irregularly-shaped accumulations of ice. However, passing tides, charged with floating ice cakes, smooth off the rough edges, fill the pores and leave a film of silt-laden water to freeze into a smooth surface layer of ice. Before long, the trapezoidal cross-sections of tidal creeks, with side slopes of about 1:3.5 (see Fig. 6), are transformed into rectangular channels of much smaller cross-sectional area (Desplanque and Bray, 1986). This process in turn reduces the tidal prism, and eventually also the speed of the tide in the estuary.

Ice walls can build up to $5 \mathrm{~m}$ high in a week or less. Typically the ice forms a levee that is higher beside open water than toward the bank of a tidal creek. The base of an ice wall tends to be slightly lower than the level reached by the lowest High Waters occurring during the freezing period. Ice stranding occurs shortly following High Water, because the water continues to move into the estuary under its own inertia, delaying filling of the upper parts of the estuary. Ice that is lifted onto the top of the banks, or onto previously stranded ice, is left high and dry when the ebb sets in. This ice will likely become solidly frozen to the underlying base and will not be refloated. Should it break loose on a rising tide, it will become stranded further into the estuary. The process sounds mundane perhaps, but in actual fact it is a most remarkable exercise in ice block gymnastics. The delayed release of ice blocks from the substrate beneath the rising tidal waters causes them to be ejected by buoyancy as if possessed of life.

\section{Astronomical CYCLES AND ICE BUILD-UP}

Ice build-up in the Bay of Fundy will be heavier during some winters than in others because of tidal conditions. This is because peaks of perigean tides and spring tides coincide in cycles of 206 days (Desplanque, 1967). Two of these cycles last 412 days, with the result that from year to year the extra strong tides occur 47 days later (412-365). During the first half of the 206-day cycle, the difference in height between neap tide and spring tide is decreasing, or below average, allowing a lesser ice wall build-up. Conversely, during the second half of the cycle, tides will gradually rise to higher levels during the week before the perigean tides. Thus, one of the key factors in heavy ice build-up is the timing of the greatest difference between neap tide levels and spring tide levels, the optimal time for overflow in any season. This occurs one or two months before the perigean and spring tides combine to form the strongest tide of the cycle because during this time ice will not have been built up to a maximum. Thus, when the latter half of the 206-day cycle occurs during the freezing period between December and the end of March, one can expect the greatest build-up of ice walls. The most opportune years for this condition to develop are 1998, 2016, and 2034.

The formation of high ice walls in the Bay of Fundy as first recorded by Henry Y. Hind, occurred on, or near, April 25, 1875. One hundred days earlier, the spring tide was at its minimum. Thus, the latter half of the 206-day cycle fell during the first period, allowing ice to accumulate on the strand a month early, with accumulation probably peaking toward the end of April.

Naturally, the ice walls on either side of an estuary converge inland. In a strongly reduced channel, freshwater runoff takes over the main role in channel-shaping near the up- 


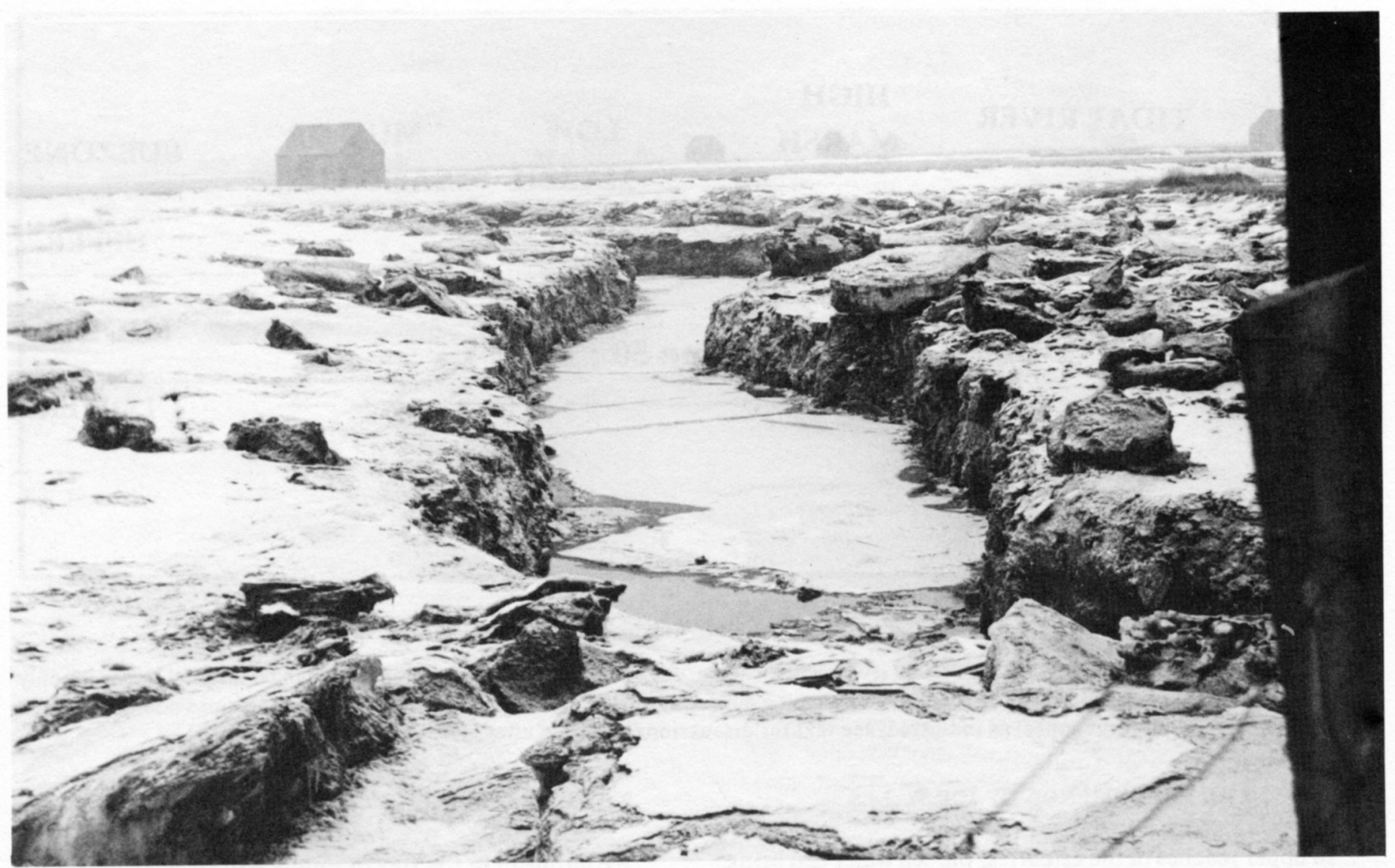

Fig. 7. Tantramar River at the Middle Marsh Road, Sackville, New Brunswick, March 22, 1954. Here the ice wall formed in January and had some ice cakes deposited on top of it during the high tides in February. Shorefast ice is starting to break up. The rough sides of the ice wall show that not much water is reaching it during High Water. Fundy tides were in fact relatively low during 1954 . (Photograph by C. Banks.)

per end of an estuary (see also Knight and Dalrymple, 1976; Forbes $e$ t al., 1995). The drastic reduction in cross-sectional area can lead to flooding during a sudden winter thaw or spring break-up. The channel may then become choked with freshwater runoff, and/or ice. Inevitably, some rivers are more prone than others to such flooding.

\section{HAZARDS vS BENEFITS OF ICE WALLS}

The development of ice walls can contribute to disastrous problems in tidal waters (Gordon and Desplanque, 1981). Consider, for example, a fertilizer plant built in 1965 at Dorchester Cape, New Brunswick, near the confluence of the Memromcook and Petitcodiac River estuaries (see Fig. 1). In order to handle bulk material to and from the plant, a wharf was constructed nearby. Because of the large local tides, a multimillion dollar floating dock was constructed. This took the form of a $25 \mathrm{~m} \mathrm{x}$ $90 \mathrm{~m} \times 7 \mathrm{~m}$ concrete caisson connected to a wharf and concrete platform on shore by means of a bridge and connecting arms. At this location, the average range of the tide is over 11 $\mathrm{m}$. During large tides, the range exceeds $15 \mathrm{~m}$. As trucks had to move over the bridge, the slope needed to be within certain limits. Hence the distance between platform and caisson was substantial. Also, the tidal channel was dredged, allowing the caisson and ships tied to it to move freely up and down with the tide.

The facility was officially opened, and named the "Port of Moncton". The first ship arrived on November 24, 1965. During the ensuing winter an ice wall developed along the shoreline, and worse, between the platform and the caisson beneath the caisson arms. In a very short time this wall became sufficiently high and strong to block the free movement of the connecting arm and bridge. Then as the tide dropped, it left the caisson more or less dangling at the end of the bridge. The result was that the bridge and the connecting arm buckled and broke, setting the caisson free. It eventually stranded on a silt flat in mid stream, some distance away.

What are the ecological implications of ice in the upper reaches of the Bay of Fundy? At one time it was believed that ice moving from the high marsh during winter was the main agent responsible for transporting organic matter from the marsh into the bay (cf. Gordon and Desplanque, 1983). However, during most winters, ice is unable to move onto the high marsh. Thus the organic detritus of high marsh vegetation survives until spring, to disappear beneath fresh vegetation in the same manner as non-cut grasses on upland meadows, presumably by microbial decomposition.

Decaying high marsh vegetation is also commonly deposited along the dykes in thick accumulations (Nova Scotia 


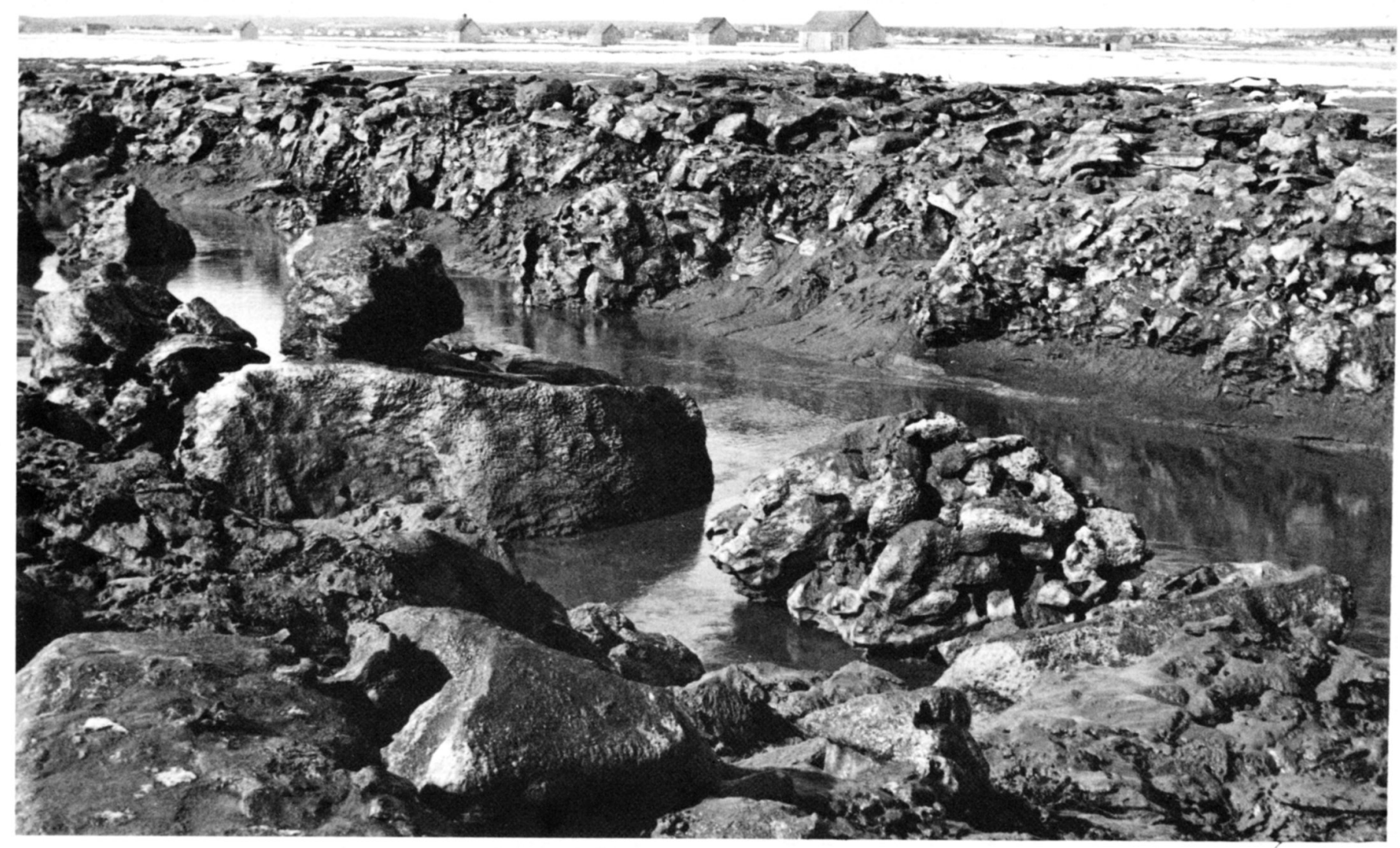

Fig. 8. Tantramar River, March 22, 1954, between the CBC transmitter and Middle Marsh Road, about $2 \mathrm{~km}$ downstream from location shown in Figure 7. The tide was able to enter this section of the river (closed off by control gates ca. 1960) where an incomplete ice wall formed. Ice block in right foreground is a conglomerate of many smaller ones. Left of centre, an ice block in stranded on top of another one, and frozen to it. Silt indicates that the ice was overtopped by the tide. (Photograph by C. Banks.)

Department of Agriculture and Marketing, 1987). Hydraulic conditions on the marsh are such as to inhibit much seaward movement of organic debris. Quite simply, the flow is too slow at these shallow depths to accomplish the transport.

On the low marsh, exposed vegetation is crushed and frozen into blocks of ice. Subsequently, these blocks may be lifted by the spring tide, pulling the partly encased vegetation from the marsh. Removed to higher elevations they will remain stranded until the ice thaws, leaving the vegetation behind.

In tidal rivers, ice walls begin to collapse by the end of March and most ice disappears, except that shorefast ice can persist until late April (see Figs. 7 and 8). Stranding of large blocks of ice on the mud flats, acting in concert with the bellows action of sheet ice hinged to the shoreline, may cause the complete reworking of the soil under the sheet ice during the late winter and early spring. Just after the ice has disappeared, some of the tidal flats resemble plowed fields, with great scars left by chunks of moving ice. Any form of life in this mudflat ecosystem survives only under a great deal of stress. Macrofaunal diversity is low. In addition to organic secretions of diatoms, most of the productive biomass is comprised of three species (Hicklin et al., 1980): a bivalve (Macoma balthica), a polychaete (Heteromastus filiformis) and the amphipod Corophium volutator. The last mentioned species, so especially important to migrating bird life in the Fundy, is widely distributed over the mudflats. Its survival in winter is doubtless predicated by its ability to burrow well beneath the zone of scour and erosion. Because ice scouring is most intense on the outer portions of mudflats, the role of shorefast ice may afford an important protection to these species in the inner several hundred metres of mudflats at estuary mouths. C. volutator may, of course, also occur on exposed tidal flats with no shortfast ice.

With approaching spring, flows of freshwater and tidal water will progressively undercut the basal portion of ice walls and ice blocks. The result is the appearance of dark-coloured, ephemeral, toadstool-shaped formations charged with concentrations of estuarine mud up to $18 \%$ by weight. By early April, the thinner ice will have disappeared, although ice walls may persist until month's end. At their base, huge accumulations of silt occur in sections sheltered from strong currents. Of course, construction of causeways promotes silt accumulation even more efficiently, with concomitant reduction in the depth of the tidal river, and dire results for much of the aquatic life (Daborn and Dadswell, 1988).

In hindsight, it transpires that the river and its ice accumulations act like an enormous hydraulic sluice. Thus, whereas ice walls and associated phenomena may prove hazardous to man-made constructions, they serve very important natural 
purposes. By their very smoothness, ice walls effectively resist further narrowing of the channel, increase the net ebb and river flushing currents, maintain river depth, increase the surface slope seaward, force the salinity intrusion seaward, and obstruct massive influx of ice from the estuary mouth.

\section{Conclusions}

Vigorous interplays between land and sea occur in northern macrotidal regimes. In Bay of Fundy estuaries, the rising sea level continually reestablishes salt marshes at higher levels despite infrequent flooding. The largest tides arrive in sets of 7 months, 4.53 years and 18.03 years, and most salt marshes are built up to the level of the average tide of the 18-year cycle. Three main astronomical tide-generating factors determine the number of tides that can exceed a certain elevation during any given year: the variable distance between the earth and the moon, the variable positions of the moon, sun and earth relative to each other, and the declination of the moon and sun relative to the earth's equator. Assuming local marsh level to be $1.2 \mathrm{~m}$ below the high water level during extreme high tides, an empirical High Marsh Curve allows the number of annual floodings to be determined.

Marigrams constructed for estuaries of rivers feeding into the Bay of Fundy show how the tidal wave is progressively reshaped over its course, and that its sediment-carrying and erosional capacities vary as a consequence of changing water surface gradients.

Changing seasons effect substantial alterations in the character of estuaries. This is especially true during winter when ice conditions develop during the second half of the 7month cycle. At this time, the difference in height between neap tide and spring tide is increasing, resulting in the optimal time for flooding of marshlands. Thus, winter contributes additional variations to an already complex tidal regime. Intertidal ice in Fundy estuaries is an extremely active agent that influences both physical and biological attributes of the bay. Heaviest ice conditions occur one or two months before perigean and spring tides combine to form the largest tide of the cycle. Already, by 1875 , Hind had elegantly described the behaviour of ice in the lower zone of a Bay of Fundy estuary. His concern then was with the potential impact of ice on the Baie Verte canal, proposed to link the Cumberland Basin to Northumberland Strait, a project never completed. However, contemporary construction projects and a multitude of coastal zone management schemes continue to merit quality time applied to the task of understanding the dynamic interactions between land and sea in the Bay of Fundy and in northern macrotidal regimes in general.

\section{ACKNOWLedGements}

Helpful advice has been generously contributed by Drs. J. Shaw, G. Fader, R.B. Taylor, C.T. O'Reilly and D. Frobel of the Bedford Institute of Oceanography (B.I.O.), Dartmouth, Nova Scotia. Earlier collaborations by the senior author (C.D.) with Drs. C.L. Amos and D.C. Gordon of B.I.O., and D.I. Bray of the University of New Brunswick are gratefully acknowl- edged. We thank the Federal Government of Canada for granting permission to use the photographs in Figures 7 and 8 . We are pleased to acknowledge that much of the source material for this work is derived from Maritime Marshlands Rehabilitation Administration observations (1950-1965) and Maritime Resource Management Services archives (1972-1987), Amherst, Nova Scotia. Special thanks to Dr. Paul Cant, Sackville, New Brunswick and to journal referees Drs. C. O'Reilly and C.L. Amos for their invaluable constructive criticisms of an earlier draft of this paper. This work has been supported by National Sciences and Engineering Research Council of Canada operating grant (\#8295) to D.J.M.

Amos, C.L. 1995. The dynamics of siliciclastic tidal flats. In The Geomorphology and Sedimentology of Estuaries. Edited by G.M.E. Perillo. Developments in Sedimentology, No. 53, First Edition, Elsevier, Amsterdam, pp. 273-306.

Boorman, L.A. and Hazelden, J. 1995. New marshes for old saltmarsh creation in Essex, England. Ocean Challenge, 6:3, pp. 34-37.

DABorn, G.R. and DAdswell, M.J. 1988. Natural and anthropogenic changes in the Bay of Fundy - Gulf of Maine - Georges Bank System. In Natural and Man-Made Hazards. Edited by M.I. El-Sabh and T.S. Murty. First Edition, D. Reidel Publishing Company, pp. 547-560.

Davis, D.S. 1943. Empirical Equations and Nomography. McGrawHill, 200 p.

DAvis, R.A., JR. 1994. The Evolving Coast. Scientific American Library, $231 \mathrm{p}$.

Desplanque, C. 1952. De dykelands in de Maritime Provinces van Canada. Tijdschrift van de Nederlandse Heidemaatschappij, 63:1, pp. 14-20.

--- 1967. Ice conditions in tidal rivers and estuaries. Unpublished report of Rural Development Branch, Maritime Resource Management Services, Amherst, Nova Scotia, 26 p.

Desplanque, C. and Bray, D.I. 1986. Winter ice regime in the tidal estuaries of the northeastern portion of the Bay of Fundy, New Brunswick. Workshop on the Hydraulics of River Ice. Canadian Journal of Civil Engineering, 13, pp. 130-139.

Dionne, J.C. 1989. An estimate of shore ice action in a spartina tidal marsh, St Lawrence Estuary, Quebec, Canada. Journal of Coastal Research, 5:2, pp. 281-293.

EL-SABH, M.I. and SILverberg, N. 1990. Oceanography of a LargeScale Estuarine System - the St. Lawrence. Coastal and Estuarine Studies, 39, Springer-Verlag, $434 \mathrm{p}$.

Forbes, D.L., Orford, J.D., Carter, R.W.G., Shaw, J., and Jennings, S.C. 1995. Morphodynamic evolution, self-organization, and instability of coarse-clastic barriers on paraglacial coasts. Marine Geology, 126:1-4, pp. 63-85.

Gordon, D.C. and DesplanQUE, C. 1981. Ice dynamics in the Chignecto Bay region of the Bay of Fundy. Proceedings of the Workshop on Ice Action on Shores, Rimouski, Quebec. Sponsored by the Associate Committee for Research on Shoreline Erosion and Sedimentation, National Research Council of Canada, Ottawa, pp. 35-52.

Gordon, D.C., JR. and Desplanque, C. 1983. Dynamics and environmental effects of ice in the Cumberland Basin of the Bay of Fundy. Canadian Journal of Fisheries and Aquatic Sciences, 40:9, pp. 1331-1342.

Gordon, D.C., Cranford, P.J., and Desplanque, C. 1985. Observations on the ecological importance of salt marshes in the Cumberland Basin, a macrotidal estuary in the Bay of Fundy. Estuarine Coastal and Shelf Science, 20, pp. 205-227. 
Greenberg, D. 1987. Modeling tidal power. Scientific American, 255:11, pp. 128-131.

Hicklin, P.W., Linkletter, L.E., and Peer, D.L. 1980. Distribution and abundance of Corophium volutator (Pallas), Macoma balthica (L.) and Heteromastus filiformis (Clarapede) in the intertidal zone of Cumberland Basin and Shepody Bay, Bay of Fundy. Canadian Technical Report of Fisheries and Aquatic Sciences, No. 965, pp. 69-77.

Hind, H.Y. 1875. The ice phenomena and tides of the Bay of Fundy. The Canadian Monthly and National Review, 8:3, pp. 189-203.

JENNINGS, S.C., CARTER, R.W.G., and ORFORD, J.D. 1993. Late Holocene salt marsh development under a region of rapid relative-sealevel rise; Chezzetcook inlet, Nova Scotia: implications for the interpretation of palaeomarsh sequences. Canadian Journal of Earth Sciences, 30:7, pp. 1374-1384.

Johnson, D. 1925. The New England-Acadian Shoreline. Hafner, New York, 609 p.

KJERFVE, B. (editor). 1988. Hydrodynamics of Estuaries (volumes 1 and 2). CRC Press Inc., 163 and 125 p.

KNight, R.J. and Dalrymple, R.W. 1976. Winter conditions in a macrotidal environment, Cobequid Bay, Nova Scotia. In Le Glaciel. Edited by J-C. Dionne. La Revue de Géographie de Montreal, 30:1 and 2, pp. 5-85
Maritime Marshland Rehabilitation Administration. 1950-1965. Annual Reports on Activities under the MMRA Act. Canadian Department of Agriculture.

Nova Scotia Department of Agriculture and Marketing. 1987. Maritime Dykelands: The 350 Year Struggle. Government of Nova Scotia, Halifax, Nova Scotia, 110 p.

Postma, H. 1967. Sediment transport and sedimentation in the estuarine environment. In Estuaries. Edited by G.H. Lauff. American Association for the Advancement of Science, Washington, D.C., Publication 83, pp.158-179.

Scotr, D.B. 1980. Morphological changes in an estuary: a historical and stratigraphical comparison. Geological Survey of Canada, Paper 80-10, pp.199-205.

Shaw, J., Taylor, R.B., Forbes, D.L., Solomon, S.M., and Ruz, M.-H. 1994. Sensitivity of the coasts of Canada to sea-level rise. Geological Survey of Canada, Open File 2825, 114 p. and map.

Sweet, C.E. 1967. Preliminary report of ice conditions in Minas Basin, Chignecto Bay and the Annapolis Basin area of the Bay of Fundy. Unpublished Report submitted to the Atlantic Tidal Power Programming Board, Halifax, Nova Scotia, 22 p.

Editorial Responsibility : G.L. Williams 